\title{
Daily and annual circarhythms activity in the South American sea lion Otaria flavescens (Carnivora: Otariidae) at the central zone of Chile
}

\author{
Circaritmos de actividad diarios y anuales en el lobo marino común Otaria flavescens \\ (Carnivora: Otariidae) en la zona central de Chile
}

Maritza Sepúlveda, Doris P. Oliva and Francisco J. Palma

Facultad de Ciencias, Universidad de Valparaíso

Av. Gran Bretaña 1111, Playa Ancha, Valparaíso. Chile.

msepulv@altavista.com

\begin{abstract}
In otariids the presence of circarhythms activity has been studied on the basis of population density changes in sea lion colonies. In this work, the circadian rhythm (24 h) and the circannual rhythm (a year) of the South American sea lion Otaria flavescens from Cochoa and Punta Curaumilla colonies in Central Chile were studied.

The circadian rhythm was studied in both colonies. In each one, census were performed every 45 minute during three days (72 h) of continuous observation. The results show that the number of animals on land increases during day times and decreases in the night. Such fluctuations are associated to a $24 \mathrm{~h}$ cycle and show the existence of a circadian rhythm in these colonies.

The circannual rhythm was studied at Cochoa colony. With this purpose 145 observations were performed during three consecutive years (1995-1998). The results show a population increase during Autumn and Spring and a sudden decrease in the Summer. These fluctuations are associated to a one year cycle showing the existence of a circannual rhythm in this species.

Key words: South American sea lion, Otaria flavescens, Otaria byronia, circadian rhythm, circannual rhythm.
\end{abstract}

Resumen.- En otáridos se han estudiado la presencia de circaritmos de actividad sobre la base de cambios en las densidades poblacionales en las loberas. En este trabajo, se estudiaron los ritmos circadiano (24 h) y circanual (1 año) del lobo marino común Otaria flavescens en las loberas de Cochoa y Punta Curaumilla en Chile Central.

El ritmo circadiano fue estudiado en ambas loberas. En cada una de ellas se realizaron censos cada 45 min durante 3 días de observación continuos (72 h). Los resultados demuestran que se produce un aumento del número de animales en tierra en horarios diurnos y una disminución en los nocturnos. Dichas fluctuaciones están asociadas a un ciclo de 24 h, y demuestran la existencia de un ritmo circadiano en estas loberas.

El ritmo circanual fue estudiado en la lobera de Cochoa. Para ello se realizaron 145 observaciones durante 3 años consecutivos (1995-1998). Los resultados muestran un aumento de la población en los meses de otoño a primavera, y una disminución brusca en el verano. Estas fluctuaciones se asocian a un ciclo de un año, y demuestran la existencia de un ritmo circanual en esta especie.

Palabras clave: Lobo marino común, Otaria flavescens, Otaria byronia, ritmo circadiano, ritmo circanual.

\section{Introduction}

In living organisms, there are numerous phenomena which are regularly repeated obeying to some sort of internal clock showing a rhythm associated to external cycles (Marler \& Hamilton 1966, Brady 1979). Depending on the frequency of the repetition of these rhythms may become circatidal (12,4 h), circadian (24 h), circasemilunar (15 d), circalunar (29 d) or circannual (1 yr) (Palmer 1990, Pino et al. 1994).

In some species of otariids, the presence of these circarythms has been studied based on the changes of the population density in the colonies. Changes attributed to feeding and reproductive behaviors. An example of this are the works by Mathisen \& Lopp (1963) and Ainley et al. (1982) which demonstrate the existence of circadian rhythms in Eumetopias jubatus and Zalophus californianus, respectively. These authors state that the majority of the animals go out for feeding at sunset coming back just a moment before the sunrise. In Otaria flavescens (Shaw 1800), Rosas et al. (1994) describe the existence of the same behavioral pattern in which groups go out during the sunset and come back when the day is breaking registering the largest number of animals on land at noon. These fluctuations do suggest the presence of a circadian rhythm in this species which might be associated to their feeding activity.

A circannual rhythm - mainly conditioned by the reproductive activity - has also been described for the South American sea lion (Oliva 1984). The reproductive 
period for the $O$. flavescens extends from December to March (Cabrera \& Yepes 1940, Aguayo \& Maturana 1973, Vaz-Ferreira 1975); during this period the animals concentrate in colonies (Carrara 1952). In accordance to the activity to be developed the colonies are classified in reproductive and resting colonies which are mainly characterized by the presence or absence of pups, respectively (Sielfeld et al. 1997).

During the reproductive period most of the animals stay, going only sporadically to the sea. Thus, once this period is over, the great majority spread to the resting colonies in search of food and rest (Hamilton 1939, Piazza 1959). From this point of view, the reproductive and resting places differ not only by the prevailing activity but also by the fluctuations in the number of animals during the year. While in the place of birth there is an increase in the population during Summer and a decrease in the other seasons. The contrary might be seen in the resting place where it is possible to find the largest number of individuals out of their reproductive period.

Based on what has been presented, the aim of this study is to determine if the South American sea lions experiment daily or annual population fluctuations which may be associated to the circarhythms activity in this species and also be associated to their feeding and reproductive activities.

\section{Methods}

\section{Study area}

The circarhythm activity in the South American sea lion was studied through periodical census at Cochoa (32 ${ }^{\circ} 7^{\prime}$ S; $71^{\circ} 33$ 'W), and at Punta Curaumilla colonies (3306' S; $\left.71^{\circ} 44^{\prime} \mathrm{W}\right)$ (Fig. 1).

Cochoa colony is a $15 \mathrm{~m}$ long and $7 \mathrm{~m}$ wide coastal islet, and with a height close to $6 \mathrm{~m}$ above sea level. The only species living on this rookery is the South American sea lion which is distributed all over the area.

Punta Curaumilla colony is also a coastal islet whose dimensions are about $500 \mathrm{~m}$ long, $350 \mathrm{~m}$ wide, and a height of $80 \mathrm{~m}$ above sea level. The South American sea lion is distributed in five different areas located to the north and east of the islet.

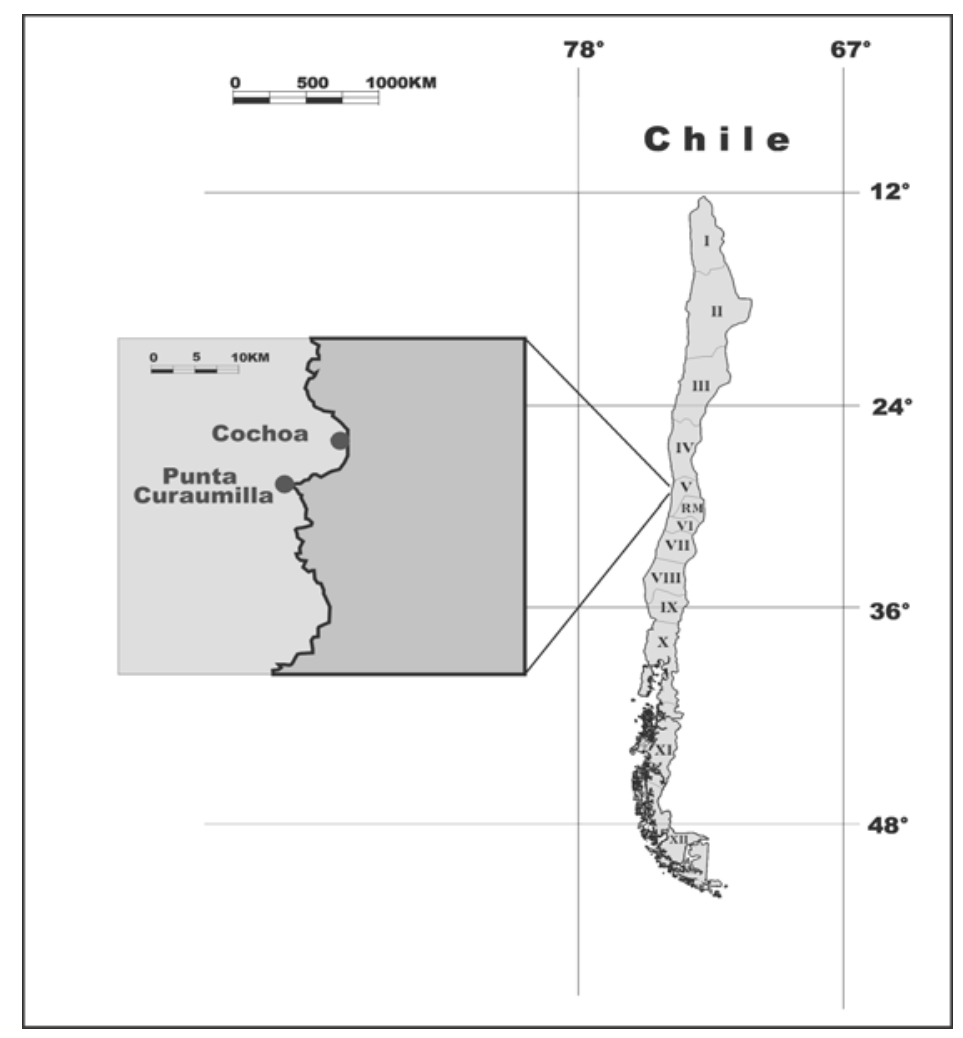

Figure 1

Geographic location of Cochoa and Punta Curaumilla colonies.

Ubicación geográfica de las loberas de Cochoa y Punta Curaumilla. 


\section{Census methodology}

Each census recorded the total amount of animals. They were separated - as per their morphological characteristics - to the following categories (Hamilton 1934, King 1983, Oliva 1984): adult male, sub-adult male, female, juvenile, and pups. Apart from these categories, an indeterminate category was included to place those animals which due to their location in the colonies could not be incorporated to any of the previous categories.

The daily fluctuations of the South American sea lion population was studied at Cochoa colony from the 22nd to the 24th of July, 1997, and at Punta Curaumilla colony from the 21st to the 23rd of November, 1997; both studies were performed out of the reproductive period of this species. In each site, a follow up of three consecutive days was made. The observations started at 00:00 h, with 45 min intervals, until 23:15 h, giving a total of 32 observations per day. According to Oliva (1984) this represents the optimum number of census to be performed during one day because - if compared to continuous observations - only a $2 \%$ of the information is lost.

During the hours of darkness (20:15 - 6:45) a CJ-230 quartz halogen lamp, $100 \mathrm{~W}$, was used to illuminate the colonies. At Punta Curaumilla, the observer's position obstructed the categorization of the animal during this period of time. Therefore, only the total quantity of animals was counted.

The annual fluctuations were studied at the Cochoa colony. For that purpose, weekly census were performed from April 1995 through March 1998 completing a total of 145 census. As the number of animals varies according to the time of the day, each observation was performed between 12:00 and 15:00, lapse in which the largest number of animals is on shore (Oliva, 1984).

Because of some factors affecting the number of present animals in a colony at determined moments (meteorological conditions, presence of artisan fishermen, etc.), a monthly average of the census was made, so as to eliminate or, at least, reduce these border data.

\section{Statistical analysis}

The Kruskal-Wallis test was applied to the results of the daily and annual census in order to establish if there was a periodicity in the fluctuations of the number of present animals in the colonies (Siegel 1972). In those series showing periodicity an harmonic regression model (MRA) was used (Bloomfield 1976). The equation used in this model was as follows:

$$
y(t)=\mu+\sum_{j=1}^{n}\left(A_{j} \cos w j t+B_{j} \operatorname{sen} w j t\right)+E
$$

$\begin{array}{lll}\text { Where: } & & \\ \mathrm{y}(\mathrm{t}) & : & \text { number of animals observed in a time } \\ \mu, \mathrm{A}_{\mathrm{j}} \mathrm{y} \mathrm{B}_{\mathrm{j}} & : & \text { parameters of the model } \\ \mathrm{w} & : & \text { angular frequency } \\ \mathrm{E} & : & \text { non-observable random errors }\end{array}$

As the resulting equation is not lineal the parameters were estimated in an iterative way through the QuasiNewton numerical method (Fuller 1976). In turn, the angular frequency (number of cycles per unit of time) was estimated through spectral analysis which allowed the identification of the seasonal fluctuations and their importance (Fuller 1976). The angular frequencies used in this analysis were $0.01,0.02,0.03$ and 0.04 .

At Punta Curaumilla colony the statistical analyses were performed on the total amount of animals without including the categories.

\section{Results}

In Cochoa and Punta Curaumilla colonies, the population of this species is composed by adult male, sub-adult male, female and juvenile individuals. Based on the existing literature and due to the fact that no parturition was observed during the period under analysis, these colonies are considered resting areas.

The results of the census performed during three consecutive days at Cochoa and Punta Curaumilla colonies are shown in Figs. 2 and 3, for each of the categories considered (except for the indeterminate ones) and the total amount of animals.

Table 1 shows the estimator $\mathrm{H}$ and the significance level of the Kruskal-Wallis test. Table 2 shows the MRA parameters and the variance explained by the daily census.

The resulting MRA adjustment curve for each category and the total amount of specimen in both colonies are included in Figs. 2 and 3. In this model, the wave peaks and valleys represent the periods in which the largest and the smallest amount of animals was found, respectively.

Both the MRA adjustment curve and the KruskalWallis test show that the fluctuations in the amount of animals present a periodicity which is associated to a $24 \mathrm{~h}$ cycle. Thus, on each day, the lower amount of animals on land is found at night. In daylight the population increases until reaching a maximum peak during the first hours of the afternoon. After this period the animals leave the colony. The lowest amount of animals is found at night. This indicates that the South American sea lion presents a circadian activity rhythm at the Cochoa and Punta Curaumilla colonies. 
(a)
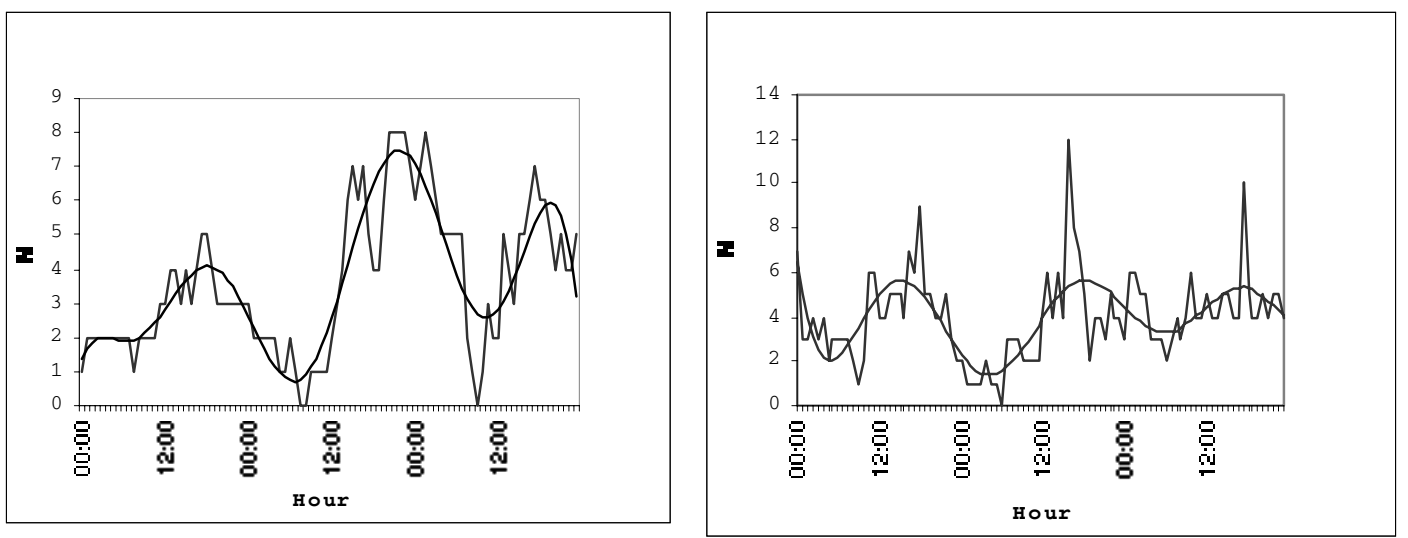

(b)

(c)
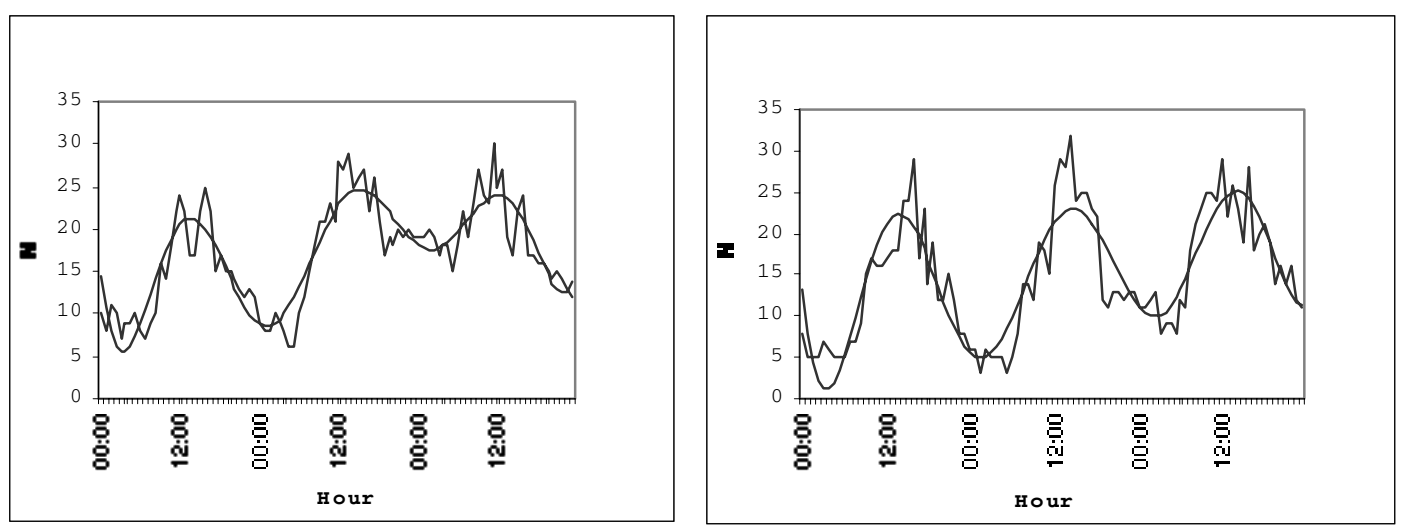

(d)

(e)

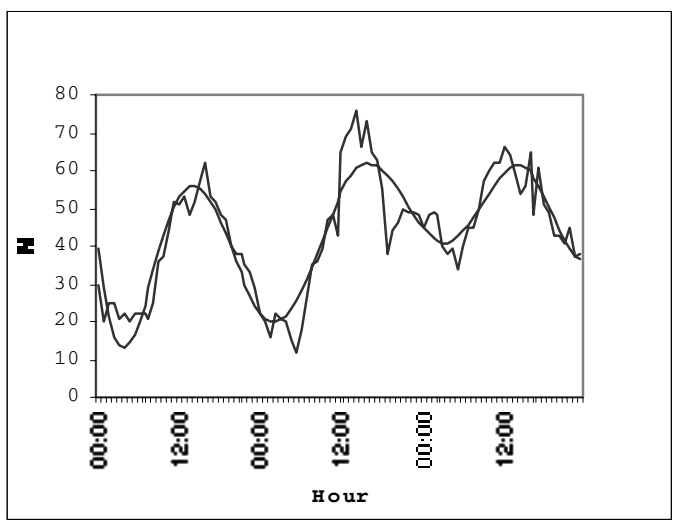

Figure 2

Number of sea lions and MRA adjustment curve at Cochoa colony during three consecutive circadian rhythms (July 22-24, 1997). (a) adult male; (b) sub-adult male; (c) female; (d) juvenile; and (e) total amount of animals.

Número de lobos marinos y curva de ajuste del MRA en la lobera de Cochoa durante tres ritmos circadianos consecutivos (22-24 de julio, 1997). (a) machos adultos; (b) machos subadultos; (c) hembras; (d) juveniles y (e) total de animales. 


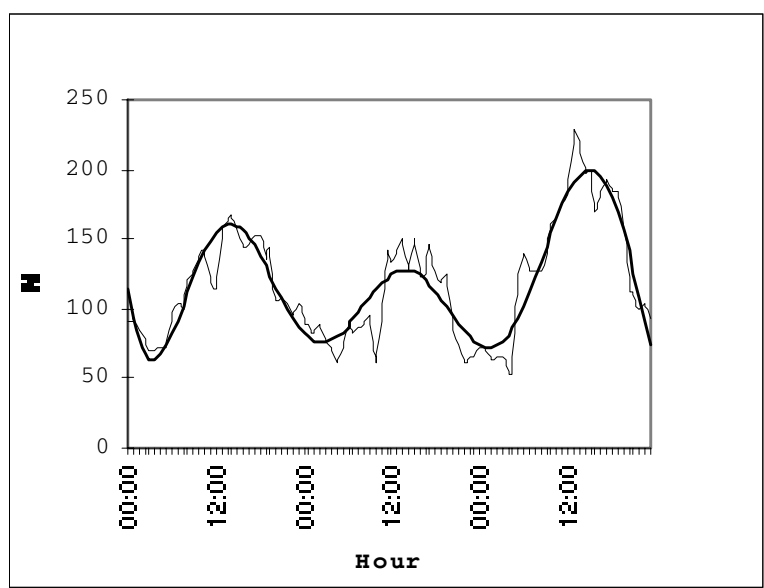

Figure 3

Total amount of sea lions and MRA adjustment curve at

Punta Curaumilla colony during three consecutive circadian rhythms (November 21-23, 1997).

Total de lobos marinos y curva de ajuste del MRA en la lobera de Punta Curaumilla durante tres ritmos circadianos consecutivos (21-23 de noviembre, 1997).

\section{Table 1}

Estimator $H$ and $P$, apply to three consecutive circadian rhythms of the South American sea lion at Cochoa and Punta Curaumilla colonies.

Estimador $\mathrm{H}$ y $P$, aplicados a tres ritmos circadianos consecutivos del lobo marino común en las loberas de Cochoa y Punta Curaumilla.

\begin{tabular}{|l|c|c|c|c|}
\hline \multirow{2}{*}{ Category } & \multicolumn{2}{c|}{ Cochoa } & \multicolumn{2}{c|}{ Punta Curaumilla } \\
\cline { 2 - 5 } & H & $\boldsymbol{P}$ & H & $\boldsymbol{P}$ \\
\hline Adult Male & 11.44 & 0.03 & - & - \\
\hline Sub-Adult Male & 8.14 & 0.02 & - & - \\
\hline Female & 11.91 & 0.00 & - & - \\
\hline Juvenile & 5.95 & 0.05 & - & - \\
\hline Total & 9.82 & 0.00 & 9.58 & 0.01 \\
\hline
\end{tabular}

Table 2

Parameters of the MRA y $\mathbf{R}^{2}$, adjusted to three consecutive circadian rhythms of the South American sea lion at Cochoa and Punta Curaumilla colonies.

Parámetros del MRA y $\mathrm{R}^{2}$, ajustados a tres ritmos circadianos consecutivos del lobo marino común en las loberas de Cochoa y Punta Curaumilla.

\begin{tabular}{|c|c|c|c|c|c|c|}
\hline Parameter & & & Cochoa & & & P. Curaumilla \\
\hline & Adult m. & Sub-Adult m. & Female & Juvenile & Total & Total \\
\hline$\mu$ & -1567.40 & 1135.54 & 7222.85 & 8099.47 & 15276.09 & 26004.43 \\
\hline A1 & 1515.42 & -1052.11 & -6842.19 & -7634.75 & -14366.00 & -24051.30 \\
\hline B1 & 806.33 & -651.76 & -3908.19 & -4460.21 & -8438.83 & -15030.3 \\
\hline $\mathrm{A} 2$ & 58.03 & -69.9202 & -357.78 & -429.52 & -825.19 & -1670.31 \\
\hline B2 & -146.57 & 91.73 & 640.85 & 704.02 & 1319.63 & 2130.76 \\
\hline A3 & -3.52 & -2.58 & 4.47 & -3.82 & -6.96 & -85.18 \\
\hline B3 & -12.92 & 10.47 & 66.08 & 76.32 & 143.39 & 285.55 \\
\hline A4 & -1.63 & -2.79 & -7.47 & -11.28 & -24.19 & -55.10 \\
\hline B4 & -3.18 & 0.67 & 10.44 & 12.77 & 20.82 & 51.44 \\
\hline $\mathrm{R}^{2}$ & 0.79 & 0.44 & 0.81 & 0.79 & 0.83 & 0.85 \\
\hline
\end{tabular}

Fig. 4 shows the results of the census done in 1995 through 1998 at Cochoa colony for each one of the categories as well as for the total amount of specimen.

Table 3 indicates the estimator $\mathrm{H}$ and the significance level of the Kruskal-Wallis test. Likewise, Table 4 shows the parameters and the variance explained by the MRA at Cochoa colony.

Fig. 4 includes the MRA adjustment curve. Just like the daily census, this curve and the Kruskal-Wallis test made evident that there is a periodicity in the population fluctuations associated to a one year period. Therefore, there is an increase in the amount of animals in March, for all the categories, registering the largest amount in May through August. After this period, the population slightly decreases until December. There is a sudden decrease at the end of December which remains in January and February. These results made evident that there is a circannual rhythm in the South American sea lion at the Cochoa colony. 
(a)
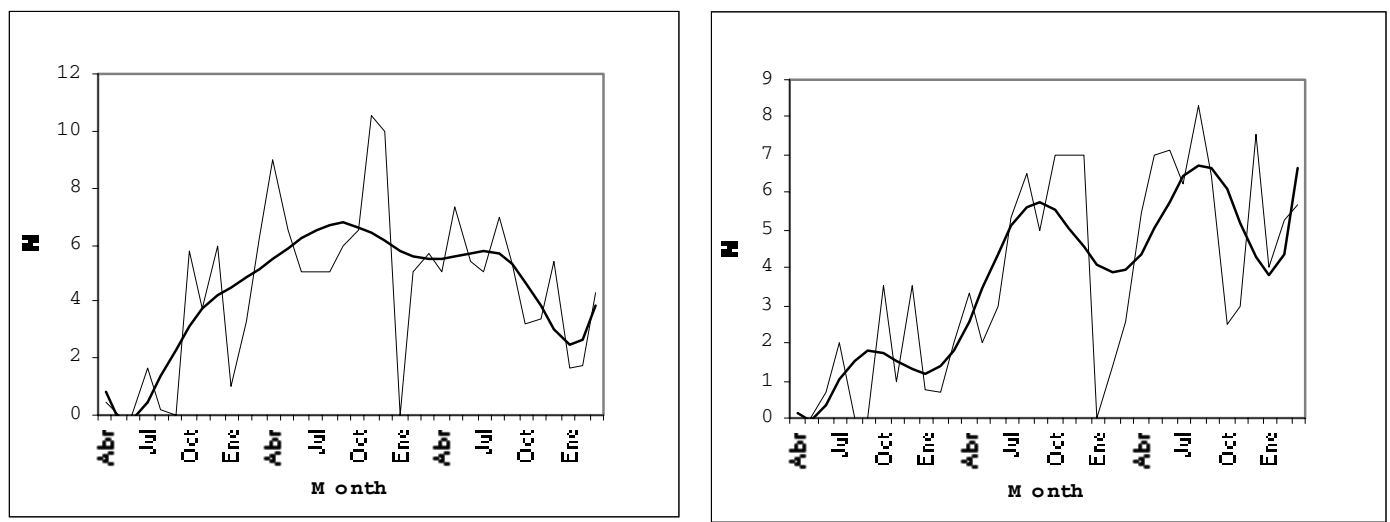

(b)

(c)
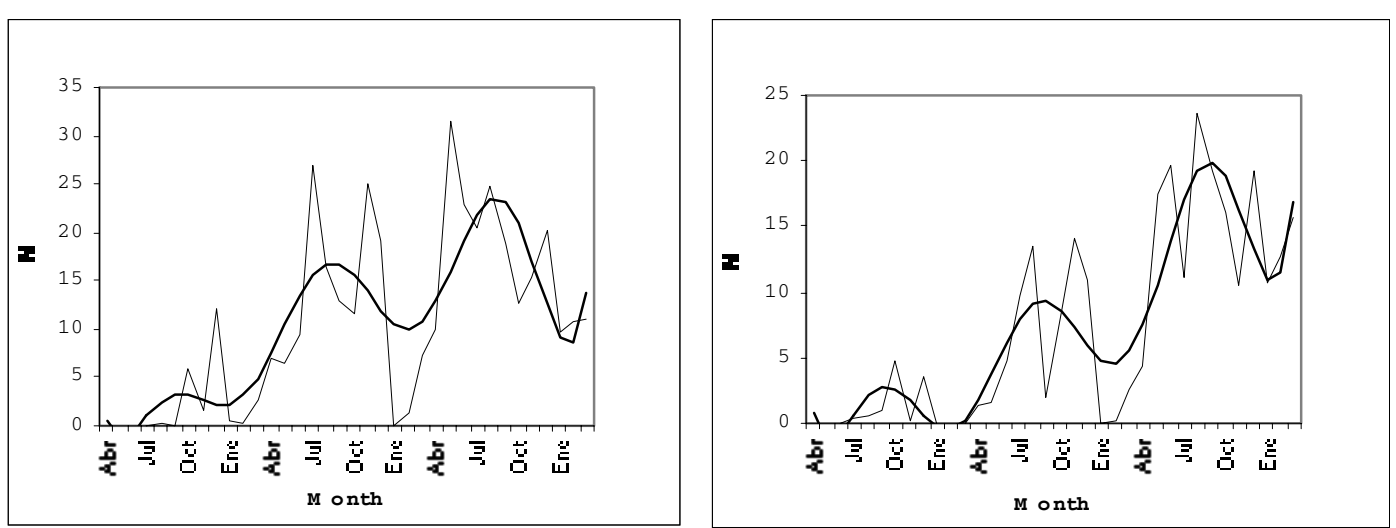

(d)

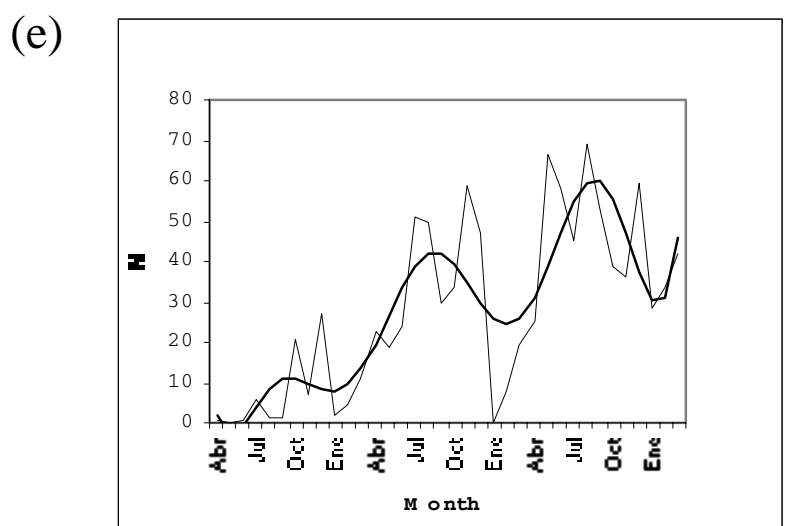

Figure 4

Number of sea lions and MRA adjustment curve at Cochoa colony during three consecutive circannual rhythms (April 1995 March 1998). (a) adult male; (b) sub-adult male; (c) female; (d) juvenile; and (e) total amount of animals.

Número de lobos marinos y curva de ajuste del MRA en la lobera de Cochoa durante tres ritmos circanuales consecutivos (abril 1995 marzo 1998). (a) machos adultos; (b) machos subadultos; (c) hembras; (d) juveniles y (e) total de animales.

Table 3

Estimator $\mathbf{H}$ and $\boldsymbol{P}$, apply to three consecutive circannual rhythms of the South American sea lion at Cochoa colony. Estimador $\mathrm{H}$ y $P$, aplicados a tres ritmos circanuales consecutivos del lobo marino común en la lobera de Cochoa.

\begin{tabular}{|l|c|c|}
\hline \multicolumn{1}{|c|}{ Category } & H & $\boldsymbol{P}$ \\
\hline Adult Male & 11.21 & 0.01 \\
\hline Sub-Adult Male & 10.86 & 0.01 \\
\hline Female & 12.69 & 0.00 \\
\hline Juvenile & 12.35 & 0.00 \\
\hline Total & 12.83 & 0.00 \\
\hline
\end{tabular}


Table 4

Parameters of the MRA y $\mathbf{R}^{2}$, adjusted to three consecutive circannual rhythms of the South American sea lion at Cochoa colony.

Parámetros del MRA y $\mathrm{R}^{2}$, ajustados a tres ritmos circanuales consecutivos del lobo marino común en la lobera de Cochoa.

\begin{tabular}{|c|r|r|r|r|r|}
\hline Parameter & Adult m. & Sub-Adult m. & Female & Juvenile & Total \\
\hline$\mu$ & 1531.02 & 1841.09 & 6237.64 & 6070.12 & 16724.69 \\
\hline A1 & -1455.81 & -1769.89 & -5968.32 & -5806.02 & -16005.50 \\
\hline B1 & -817.01 & -949.42 & -3275.21 & -3191.51 & -8769.5 \\
\hline A2 & -72.50 & -74.22 & -274.16 & -65.64 & -727.78 \\
\hline B2 & 138.53 & 170.42 & 569.43 & 548.01 & 1522.69 \\
\hline A3 & 0.88 & 4.28 & 10.38 & 9.24 & 26.38 \\
\hline B3 & 12.78 & 15.16 & 53.86 & 53.01 & 143.53 \\
\hline A4 & -0.30 & 0.32 & 1.43 & 0.26 & 2.44 \\
\hline B4 & 1.52 & 2.97 & 10.31 & 9.55 & 26.82 \\
\hline $\mathrm{R}^{2}$ & 0.52 & 0.61 & 0.61 & 0.76 & 0.69 \\
\hline
\end{tabular}

\section{Discussion}

The results of the daily census performed at Cochoa and Punta Curaumilla colonies indicate that the population fluctuations of the $O$. flavescens are associated to a $24 \mathrm{~h}$ cycle. In each one of the considered categories there is an increase of the population during daytime schedules decreasing at night.

This fact is associated to the nocturnal feeding habit of the South American sea lion. Behavior which seems to be determined by the feeding habits of their preys which concentrate mainly on the surface during the night (Thorpe et al. 1994, Fraser et al. 1995, Soto et al. 1997). In this sense, the nocturnal feeding of the South American sea lion may be favored by an energetic saving, in terms of a greater accessibility to the preys.

Based on such fact, it is possible to confirm the existence of a circadian rhythm in the South American sea lion at Cochoa and Punta Curaumilla colonies which would be related to the feeding activity.

In the case of the annual fluctuations registered at Cochoa colony, the results show the existence of an annual cyclic pattern. As this is a resting colony, the lowest amount of animals is present in summer due that on this season the animals are in their reproductive activity. When this activity is over they return to the resting colonies showing a population increase of the number of South American sea lions since March remaining until December when they leave the colony again. In this way it is possible to demonstrate a circannual rhythm in this species which is mainly associated to the reproductive activity.

The knowledge of the feeding habits of the South American sea lion might be of great help on the studies regarding the interaction of this species with the artisan fishery and salmon farming. If these productive activities emphasize the prevention of the attacks against sea lions during their feeding time, then it would be possible to decrease the economical loses registered at the present time.

\section{Acknowledgments}

We would like to thank the support provided by the Chilean Navy and the Facultad de Ciencias del Mar of the Universidad de Valparaíso, during the development of this research, and specially to Sargent Luis Zambrano, Juan Soto and Sergio Zepeda. Likewise, we emphasize the participation of Miss Flor Uribe during part of this research. We would also like to thank Manuel Galea and Rony Vallejos for the statistical support, and Ms. Alejandra Urra and Rolando Bernal for their collaboration in writing the paper.

\section{Literature cited}

Aguayo A \& R Maturana. 1973. Presencia del lobo marino común Otaria flavescens en el litoral chileno. Biología Pesquera 6: 49-75.

Ainley DG, HR Huber \& KM Bailey. 1982. Population fluctuations of California sea lions and the Pacific whiting fishery off Central California. Fishery Bulletin 80(2): 253258.

Bloomfield P. 1976. Fourier analysis of time series: an introduction, 258 p. John Wiley and Sons, New York.

Brady J. 1979. Biological clocks, 79 p. Academic Press, New York.

Cabrera A \& J Yepes. 1940. Los Otáridos. Mamíferos Sudamericanos. Historia Natural Ediar: 177-180. 
Carrara I. 1952. Lobos marinos, pingüinos y guaneras de la costa del litoral marítimo e islotes adyacentes de la República de la Argentina, 16 p. Ministerio de Educación Nacional de la Plata. Facultad de Ciencias Veterinarias (Publicación Especial) Enero 1952, Buenos Aires.

Fraser NH, J Heggenes, NB Metcalfe \& JE Thorpe. 1995. Low summer temperatures cause juvenile Atlantic salmon to become nocturnal. Canadian Journal of Zoology 73: 446451.

Fuller WA. 1976. Introduction to statistical time series, $470 \mathrm{p}$. John Wiley and Sons, New York.

Hamilton J. 1934. The southern sea lion Otaria byronia (de Blainville). Discovery Reports 8: 269-318.

Hamilton J. 1939. A second report on the southern sea lion, Otaria byronia (de Blainville). Discovery reports 19: 123164.

King JE. 1983. Seals of the world, 240 p. Cambridge University Press, Cambridge.

Marler P \& WJ Hamilton. 1966. Mechanisms of animals behavior, 771 p. John Wiley and Sons, New York.

Mathisen OA \& RJ Lopp. 1963. Photographic census of the Steller sea lion herds in Alaska, 1956-58, 20 p. United States Fish and Wildlife Service, Special Scientific Report Fisheries $N^{\circ} 424$.

Oliva DP. 1984. Espectro trófico y circaritmos de actividad alimentaria en loberías permanentes y temporarias de Otaria byronia (Blainville, 1820) (Carnivora:Otariidae), 111 p. Tesis para optar al grado de Licenciado en Biología. Universidad de Chile, Valparaíso, Chile.

Palmer JD. 1990. The rhythmic lives of crabs. BioScience 40(5): 352-358.

Piazza A. 1959. Los lobos marinos en el Perú. Pesca y Caza Lima 9: 1-29.
Pino C, DP Oliva \& JC Castilla. 1994. Ritmos de actividad en las lapas Fisurrella crassa Lamarck 1822 y F. latimarginata Sowerby 1835: Efectos del ciclo de marea y fotoperíodo. Revista de Biología Marina 29(1): 89-99.

Rosas FC, MC Pinedo, M Marmontel \& M Haimovici. 1994. Seasonal movements of the South American sea lion (Otaria flavescens, Shaw) off the Rio Grande do Sul coast, Brazil. Mammalia 58(1): 51-59.

Siegel S. 1972. Estadística no paramétrica, 346 p. Editorial Trillas, México.

Sielfeld W, C Guerra, LR Durán, E Acuña, A Aguayo, M Sepúlveda, F Palma, A Malinarich, G Cerda, A Bolvarán, R Grau, X Veloso, Y Guerra, M Vargas, $N$ Amado, $R$ Peredo \& J Galáz. 1997. Monitoreo de la pesquería y censo del lobo marino común en el litoral de la I - IV Regiones, 105 p. Informe final Proyecto Fondo de Investigación Pesquera 9528, Subsecretaría de Pesca, Valparaíso, Chile.

Soto D, A Guerrero, C Moreno, C Molinet, C Godoy, E Niklischeck, E Aedo \& X Avila. 1997. Evaluación de salmónidos de vida libre silvestre existentes en las aguas interiores de las Regiones X y XI, 99 p. Informe final Proyecto Fondo de Investigación Pesquera 95-31, Subsecretaría de Pesca, Valparaíso, Chile.

Thorpe JE, NB Metcalfe \& NH Fraser. 1994. Temperature dependence on switch between nocturnal and diurnal smolt migration in Atlantic salmon. In: Mackinlay, DD (ed): 8386. Fish Physiology Association, Vancouver.

Vaz-Ferreira R. 1975. Behavior of the Southern sea lion, Otaria flavescens (Shaw) in the Uruguayan Islands. Rapports et Procès-Verbaux des Réunions. Conseil International pour Exploration de la Mer 169: 219-227. 